\title{
By Land, By Sea, By Air ${ }^{1}$
}

\author{
Charles Jacoby, Nanette Holland, and Debbi Berger ${ }^{2}$
}

\section{UF | FLORIDIDA IFAS Extension}

The Institute of Food and Agricultural Sciences (IFAS) is an Equal

Opportunity Institution authorized to provide research, educational information and other services only to individuals and institutions that function with nondiscrimination with respect to race, creed, color, religion, age, disability, sex, sexual orientation, marital status, national origin, political opinions or affiliations. For more information on obtaining other extension publications, contact your county Cooperative Extension service.

U.S. Department of Agriculture, Cooperative Extension Service, University of Florida, IFAS, Florida A. \& M. University Cooperative Extension Program, and Boards of County Commissioners Cooperating. Larry Arrington, Dean.

\section{Copyright Information}

This document is copyrighted by the University of Florida, Institute of Food and Agricultural Sciences (UF/IFAS) for the people of the State of Florida. UF/IFAS retains all rights under all conventions, but permits free reproduction by all agents and offices of the Cooperative Extension Service and the people of the State of Florida. Permission is granted to others to use these materials in part or in full for educational purposes, provided that full credit is given to the UF/IFAS, citing the publication, its source, and date of publication.

\footnotetext{
${ }^{1}$ This document is CIR1502, an Activity in an Invasive Species Curriculum (CIR1496), and it is reprinted by permission of the Tampa Bay Estuary Program and The Florida Aquarium. Original EDIS publication date: January, 2007. It was supported by the Tampa Bay Estuary Program, the Florida Aquarium, the Department of Fisheries and Aquatic Sciences of the University of Florida, and the National Sea Grant College Program of the National Oceanic and Atmospheric Administration (NOAA), U.S. Department of Commerce, under NOAA Grant No. NA 16RG-2195. Visit the EDIS Web Site at http://edis.ifas.ufl.edu.

${ }^{2}$ Charles Jacoby, Assistant Professor, Department of Fisheries and Aquatic Sciences, Cooperative Extension Service, Institute of Food and Agricultural Sciences, University of Florida, Gainesville, 32611; Nanette Holland, Public Outreach Coordinator, Tampa Bay Estuary Program, 100 8th Avenue S.E., MS I-1 / NEP, St. Petersburg, FL 33701; Debbi Berger, Vice President of Education, The Florida Aquarium, Inc., 701 Channelside Drive, Tampa, Florida, 33602.
} 
This page was intentionally left blank. 


\section{Invasive Species}

Series
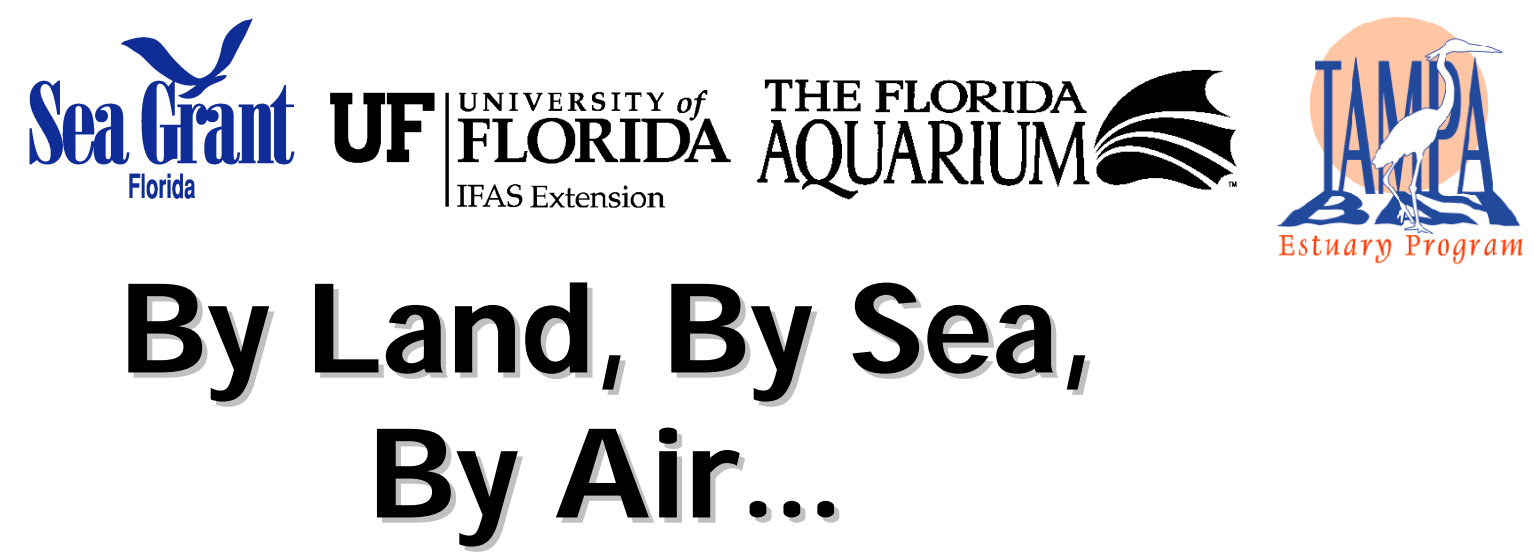

Sneak Pe eK

Students will be introduced to concepts and issues surrounding invasive and non-native

species. Students will explore how invasive species arrive in Florida. They will research the origin of a specific species and create a storyline outlining the arrival of the first individual.

This activity incorporates

information gathering, creative writing, and presentation skills.

Aligned with the following $S$ unstine State $S$ tandards and $\mathcal{F C A T}$ Benchmarks for grades $6-8:$

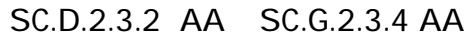

$S C . F .1 .3 .7 \quad \mathcal{C S} \quad S \mathcal{S} . \mathcal{H} .2 .2 .1 \mathrm{CS}$

SC.G.2.3.3 CS

$\mathcal{A} \mathcal{A}=$ annually assessed

CS = content sampled

\section{Objectives:}

Students will:

- Identify the pathways by which non-native species are transported.

- Collect information on a specific invasive species in Florida.

- Demonstrate an understanding of how pathways transport non-native species by creating a fictitious story of the first individual's arrival.

\section{Materials:}

- Internet access, books or resource articles on invasive species.

- Copies of Florida A quarium species fact sheets.

- Variety of costumes (not required) and craft supplies for role-play.

\section{Background:}

\section{How did they get here?}

N on-native species arrive in Florida several different ways. A pathway is the means by which a species is transported from one location and introduced into another location where it was not present. So me species are deliberately introduced by humans. The plant Kudzu was introduced to control soil erosion. N on-native ornamental plants, such as Brazilian pepper, have been used in landscaping around homes and businesses. U nusual pets, including aquatic species, have been released by owners into Florida's wild lands and waterways. 
$\mathrm{N}$ on-native species also arrive in Florida as the unintentional consequence of human activities. Ballast water can carry organisms across the world.

The process of importing fruits and vegetables can carry pests to a new location. Even the international movement of people can bring diseases or viruses wherever they may travel!

The intentional and unintentional pathways described above are enhanced or created by human activity. Species also make use of natural pathways, including wind and currents. Please visit www.invasivespecies.gov for more information.

\section{Procedure:}

1. Divide the class into groups of three. Distribute one of the Florida Aquarium species fact sheets to each group. You can also decide to let each group choose their invasive species.

2. After each group has a specific invader species, instruct them to research how the invader is thought to have arrived in Florida. If this information is not known, lead the group to speculate based on how similar species arrived.

3. O nce the class has gathered this information, instruct them to create a specific story outlining the way the original individual arrived. This should include an introduction of the human characters including their jobs or role in the story, a depiction of the trip and a description of the arrival in Florida.

4. O nce they have written the script for the presentation, they can use craft supplies or costumes to "dress up" as their characters.

5. Each group will present their "play" to the class. 


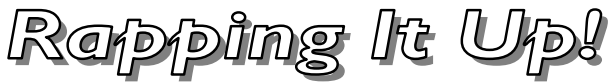

1. The non-native species in this activity all had pathways.

W as your species introduced intentionally? Describe why you think the introduction was intentional or non-intentional.

2. Non-native species are not necessarily invasive. D efine the difference between invasive and non-native.

3. You have created the arrival of the first individual of your species. W hat are ways the introduction of this species could have been prevented?

4. C an you think of any other pathways that might bring a species to Florida that you haven't heard about in this class? 


\section{Glossary:}

Ballast- W ater or other heavy material placed in the hold of a ship for stability.

Invader/Invasive species - A plant or animal that is not native and causes harm, including disrupting natural ecosystems.

Native species - A plant or animal species that originated in a certain place. A species occurring in its natural range. Species that were present in Florida at the time the first Spanish settlers arrived.

Non-native species - A species introduced to a region intentionally or accidentally.

Pathway - The means by which a species is moved from place to place and introduced. 


\section{Air Potato}

Dioscorea bulbifera

Order: Liliales

Family: Dioscoreaceae

Description: Air potato is an invasive vine in Florida, consisting of large, green, heart-shaped leaves. It can quickly grow 60-70 feet in length, which is long enough to blanket even the tallest trees like those found in hardwood hammocks. As a member of the yam family, air potato produces large numbers of aerial tubers (potato-like growths attached to the stem) that will grow into new stems. Air potato is a prohibited plant in Florida.

\section{Special Features:}

- Medicine - Dioscorea varieties contain the steroid diosgenin, which is a principle material used in the manufacture of birth control pills.

- Food for Thought - Air potato is cultivated in West Africa for their edible underground tubers. Uncultivated forms, such as in Florida, are reported to be bitter and even poisonous.

- Growth - Air potato has a winter dormant period in which stems die back to the ground. After dormancy, the underground tubers give rise to new stems, which grow very quickly often reaching 70 feet by the end of the growing season.

Similar Species: Dioscorea alata and Dioscorea sansibarensis are two other members of the yam family that are similar to the air potato. D. alata is easily distinguished from the other two species because it twines to the right instead of the left. $D$. sansibarensis twines left like the air potato, but is further characterized by its small, purplish bulbs.

Range and Habitat: The origin of air potato is uncertain, however some believe the plant is native to both Africa and Asia. Others believe it was originally native to Asia and subsequently introduced into 
Reproduction:

\begin{abstract}
Africa. Air potato often grows in hardwood forests and invades thickets, disturbed areas and tropical hammocks. It is rarely found along disturbed edges of pinelands, and because it is not salt tolerant, air potato is seldom found in marine areas as well.

Dioscorea species are dioecious, meaning they have male reproductive organs in one individual and female in the other. In Florida, flowers occur during the summer months (but not every year). The inconspicuous flowers are pleasant smelling and green to white in color. Seeds are wind-dispersed although fruit set in Florida occurs only occasionally.
\end{abstract}

\title{
Notes:
}

- History - Air potato was probably introduced into Florida as an ornamental and a food plant in about 1905 . By the early 1970 s it was already recognized as a pest plant throughout the state.

- Ecology - Potato vine is a serious weed in central and southern Florida. Vines grow as rapidly as 7 inches per day, quickly spiraling up to tree tops. The vines form dense masses that shade out trees and may eventually kill them.

- Preventative Measures - Vines grow rapidly in areas of direct sunlight so efforts to remove the plant should be concentrated in these areas first. 


\section{Armored Suckermouth Catfish}

Hypostomus plecostomus (This may not be the species in Florida.)

Additional Genera in Florida:

Pterygoplichthys sp.- Sailfin Catfish

Order: Siluriformes

Family: Loricariidae

Description: Suckermouth catfish are brownish in color and appear to have many darker spots. There are approximately 116 Hypostomus species, making identification difficult. All of the species in the Loricariidae family have large sucker mouths, and the suckermouth catfish may grow up to $18^{\prime \prime}$ in length, making it one of the largest home aquarium fish.

\section{Special Features:}

- Tolerance - Suckermouth catfishes occur in fresh running waters and brackish waters. They appear to tolerate both cold and oxygenpoor waters.

- Size - Males are smaller than females.

Range and Habitat: This species naturally occurs in tropical America, including South and Central America from Uruguay north to Panama. Their range has increased in peninsular Florida to include rivers leading to Tampa Bay and southward to the canals of southeast Miami-Dade County. Adult suckermouth catfishes are typically found in rocky streams, whereas juveniles are more common in areas rich in vegetation. Adults spend most of their time hidden and attached to the underside of logs or large rocks.

Wild Diet:

Reproduction:
Algae and detritus constitute their main food items.

Suckermouth catfish do not typically breed in captivity. In the wild, ripe males develop barbel-like appendages about their mouth, 
whereas females have a tendency to develop swollen abdomens. Eggs are spawned on the surface of substrates, such as stones or logs, or in holes. Males care for the eggs, which hatch in 3-5 days.

\section{Notes:}

- Interest to Fisheries - Suckermouth catfish are of little or no value as a food fish, although they are at least occasionally consumed in their native range.

- How Did They Get Here? - The populations established throughout Florida are believed to have been introduced through escapes from tropical fish farms and releases by aquarium hobbyists.

- Feeding - Some species are more carnivorous than others, but the species established in Florida mainly eat algae and detritus.

- Potential Impacts - The plecos' broad salinity and temperature tolerance improves their chances of expanding their range and increasing their abundance in the Gulf region.

- Additional Research - Plecos may not be a significant factor limiting nesting success of cichlids and native sunfishes. The fact is there has been no research on the subject. 


\section{Asian Swamp Eel}

Monopterus sp.

Order: Synbranchiformes

Family: Synbranchidae

Description: Asian swamp eels are often confused with a number of native animals, including the native American eel. The swamp eel has an elongate (snake-like) body with no noticeable scales or fins. The head is relatively short and the teeth are small and not easily seen. The body and head are dark, sometimes dark olive or brown above, but lighter, often light orange below. Some individuals are brightly colored with yellow, black, and gold spots over a light tan or almost-white background.

\section{Special Features:}

- Skin - The skin produces a thick mucous layer making the eels difficult to catch and hold.

- Breathing - They breathe air and can achieve up to $25 \%$ of respiration cutaneously (through the skin).

- Food Needs - They can survive for weeks without food.

- Male or Female? - The swamp eel changes from female to male as it grows older and larger. Therefore, all larger individuals are males.

- Parental Care - Large males construct bubble nests at the mouth of burrows and guard the eggs and young. A high degree of parental care is given probably assuring improved reproductive success.

Similar Species: The swamp eel introduced to the United States belongs to the genus Monopterus. There may be more than one species. Until recently scientists have used the name Monopterus albus for all U.S. populations.

Range and Habitat: Swamp eels and its relatives are native to tropical and temperate Central and South America, Africa, Australia, and India to eastern Asia (including much of China). In Asia, swamp eels are widespread 
and commonly sold live in markets as food for human consumption.

Wild Diet:

Reproduction:
Crayfish, shrimp, worms, frogs, tadpoles, and other fishes

Eggs are laid into a bubble nest in shallow water. The nest is typically not attached to vegetation but floats freely at the surface. Eggs and young are guarded by one or both parents.

\section{Notes:}

- Common Names - In addition to the name "swamp eel," other English names used for members of this group of fish include rice eel, rice-paddy eel and belut.

- What is it? - Although swamp eels are fish, they are not closely related to other eel-like fishes. Unlike the native American eel (Anguilla rostrata), swamp eels do not migrate to the ocean to spawn. More than a dozen species are included in the eel family.

- Invasion - Swamp eels were first introduced to the United States in Hawaii some time around 1900. They were first identified in the continental United States in 1994 based on specimens collected in ponds at the Chattahoochee Nature Center north of Atlanta, Georgia. The eels were first found in Florida in 1997.

- Ecology - At present, scientists are concerned about the effects that swamp eel predation can have on native fish. Some recent research indicates that swamp eels do not feed heavily on tropical fish in aquaculture ponds, so predictions of impacts remain uncertain. 


\section{Australian Pine}

Casuarina equisetifolia

Order: Casuarinaceae

Family: Casuarinales

Description: The Australian Pine is not a pine tree at all. In fact, it is not even related to the pines. A straight, up-right tree capable of reaching 70 to 90 feet or more in height, the Australian pine has escaped cultivation and become naturalized. Propagating itself on barrier beaches, road sides, and in woods as if wild, the Australian pine tree is now outlawed in many parts of Florida due to its invasive nature and rapid growth rate.

\section{Special Features:}

- Leaves - The Australian Pine appears to have long, soft, graygreen needles, but these needles are actually multi-jointed branchlets. The true leaves are small, inconspicuous, tooth-like scales whorled at joints on the tree's slender, drooping branches. Branchlet length ranges from 4-8 inches.

- Fruit - The fruit is tiny, one-seeded and forms in woody conelike clusters.

- Bark - The wood is reddish brown to gray, rough and peeling.

- Flowers - Flowers are unisexual and inconspicuous, with female flowers in small axillary clusters and male flowers in small terminal spikes.

Similar Species:

Range and Habitat:
There are 45 species of the genus Casuarina, variously known as Australian pine, beefwood, forest oak, horsetail tree and iron wood. All are large evergreen trees resembling conifers, with a thin crown of drooping branches and leaves reduced to scales.

Originating in Australia, South Pacific Islands and Southeast Asia, the Australian pine was introduced to Florida in the late 1800s. By the early 1900s, it was planted extensively in the southern half of the USA. It can also be found in the West Indies, Mexico and 
elsewhere in tropical America. In particular, the Australian pine flourishes in the warmest areas in South Florida on pine land and along exposed shores.

Reproduction:

The Australian pine reproduces with seeds, as many as 300,000 per pound, which are dispersed by birds, wind and water. Flowers are unisexual and inconspicuous with female flowers in small axillary clusters and male flowers in small terminal terminal spikes.

\section{Notes:}

- Ecological Significance - With rapid growth, dense shade, dense accumulation of plant litter, and other competitive advantages, the Australian pine is displacing and extremely destructive to native vegetation.

- Erosion - Originally planted extensively in the Southern United States to provide shade and protect against wind and erosion, the Australian pine can encourage beach erosion by displacing deep-rooted native vegetation.

- Endangered Species - Interferes with nesting of endangered sea turtles and the American crocodile.

- Life History - Not freeze tolerant; sensitive to fire. The Australian pine loses branches easily and topples in high winds because of its shallow roots. It can colonize nutrient-poor soils easily by using nitrogen-fixing microbial associations.

- Allelopathy (suppression of growth of one plant species by another due to the release of toxic substances) - The Australian pine produces compounds that inhibit the growth of native vegetation.

- Related Exotics - May be confused with other related exotics including C. glauca, which has 10-17 leaf scales per whorl, and C. cunninghamiana, which has 8-10 scales per whorl (the Australian pine has 6-8 scales per whorl). 


\section{Brazilian Pepper}

Schinus terebinthifolius

Order: Sapindales

Family: Anacardiaceae

Description: Known as the Florida holly, the Brazilian pepper is a shrub or small tree easily recognized by its dark green leaves and clusters of red berries. It is related to poison ivy and is toxic to some people. Brazilian pepper is an introduced species that can crowd out native plants, necessitating its removal in many areas.

\section{Special Features:}

- Leaves - Bright green and non-leathery in texture, the leaves are compound, meaning there are several leaflets arranged opposite each other around one stem. When crushed, the leaves smell like turpentine.

- Size - The Brazilian pepper is a multi-trunk shrub that can grow as tall as 40 feet and have a diameter of more than a foot.

- Flowers and Fruits - A female Brazilian pepper produces sprays of small yellowish-white flowers and clusters of small red berries.

- Allelopathy (suppression of growth of one plant species by another due to the release of toxic substances) - The Brazilian pepper produces compounds that inhibit the growth of native vegetation.

- Medical Uses - Virtually all parts of the Brazilian pepper have been used medicinally throughout the tropics including its leaves, bark, fruit, seeds and resin. They may be used as a topical antiseptic, aid in treating anything from a toothache to depression, respiratory infections and urinary infections.

\section{Similar Species: $\quad$ Schinus molle and Schinus aroeira}

Range and habitat: Indigenous to South and Central America, the Brazilian pepper is found in semi-tropical and tropical parts of the United States. It can grow in wet or dry soil and is salt tolerant. In addition, it appears to survive flooding, fire and drought. Widely distributed in Florida, the 
Brazilian pepper is sensitive to cold temperatures and therefore limited to protected areas in central Florida. It is an aggressive invader of disturbed habitats, and can successfully colonize several native plant communities including hammocks, pinelands and mangrove forests.

\section{Reproduction:}

Each sex occurs on a separate plant. Male flowers last only 1 day. Female flowers last up to 6 days and are insect pollinated. Fruits are usually mature by December. Birds and mammals are the chief means of dispersal. Seedlings have a high rate of survival and some can be found all year. Reproduction can occur 3 years after germination. Some trees can live for about 35 years.

\section{Notes:}

- History - The Brazilian pepper has been found in ancient religious artifacts and idols, but was brought to Florida in the 1840 s for use as an ornamental shrub.

- Status - What was once a favorite shrub now dominates 700,000 acres from North central to South Florida. It is on the state of Florida's prohibited plant list and is therefore illegal to cultivate, sell or transport.

- Ecology - The Brazilian pepper damages the shoreline by disturbing natural fish habitat. It crowds out valuable mangroves, and its shallow roots allow erosion. Brazilian pepper destroys valuable wildlife habitats in freshwater wetlands and upland pine forests, and it produces many seeds that can sprout years later.

- Growth - Winter flocks of birds love the berries, and they are credited with helping to spread Brazilian pepper. The plants resprout when burned or cut, and must be killed with with herbicides. 


\section{Brazilian Waterweed}

Egeria densa

Order: Hydrocharitales

Family: Hydrocharitaceae

Description: The slender stems of Egeria are usually a foot or two long, but can be much longer. The small leaves are strap-shaped, about one inch long and 1/4 inch wide. The leaf margins have very fine saw teeth that require a magnifying lens to see. Leaves occur in whorls of three to six around the stem. The flowers are on short stalks about one inch above the water. Flowers have three white petals and are about 3/4 inch across.

\section{Special Features:}

- Flowers - Flowers are produced in late spring and again in the fall. The intensity of flowering varies from year to year.

- Invasive Properties - Brazilian waterweed forms dense stands that restrict water movement, trap sediment, and cause fluctuations in water quality. Dense beds interfere with the recreational uses of a waterbody by interfering with navigation, fishing, swimming and water skiing.

- Propagation - A few pieces or cuttings can cause spread: aquarium dumping serves as an additional means of introduction for this invasive.

- Ideal Situation - In drought years, Brazilian waterweed appears to grow more quickly, while in years with heavy precipitation it appears to grow more slowly.

Similar Species: Brazilian waterweed may be confused with hydrilla (Hydrilla verticillata). Similar in appearance and growth, Brazilian waterweed is easily recognizable by whorled leaves exceeding $2 \mathrm{~cm}$ and by fresh plants being smooth to the touch.

Range and Habitat: Brazilian waterweed is a submerged, freshwater perennial herb, generally rooted on the bottom in depths up to 20 feet or drifting. 
It is found in both still and flowing waters, in lakes, ponds, pools, ditches, and quiet streams. It tends to form dense stands that can cover hundreds of acres and can persist until it dies back in the fall. It is found in about 30 states.

Reproduction:

Once introduced, Brazilian waterweed reproduces through the spread of plant fragments. Because all the Brazilian waterweed plants in the United States are male, no seeds are produced. Branches sprout from "double nodes" located at about eight inch intervals along the stems. If a Brazilian waterweed fragment does not have a "double node", it can not grow into a new plant.

\section{Notes:}

- Invaders! - Found in streams, ponds and lakes, this submerged plant is native to South America but was imported to North America for the aquarium trade.

- History - The earliest report of Brazilian waterweed in the United States was from Millneck on Long Island in New York, where the plant was collected in 1893. It was offered for sale in the United States in 1915, where it was recommended as a good "oxygenator" plant.

- Male or Female? - Seeds and/or female flowers have never been reported from Brazilian waterweed populations established in the United States.

- Growth - The plants initiate growth when water temperatures reach 10 degrees centigrade ( $\left.50^{\circ} \mathrm{F}\right)$. Two major growth flushes occur in spring and fall. Each of these flushes is followed by periods of die off/biomass loss.

- Nicknames - Brazilian waterweed is also commonly called Brazilian elodea. 


\section{Brown Anole}

Anolis sagrei

Order: Squamata

Family: Polychrotidae

Description: $5-8$ " long. Extensible throat fan is yellow to red-orange, with a central white line. Enlarged toe pads and short snout. Back is tan to dark brown, with dark-bordered, interconnected light diamonds or stripe. Prominent crest on males' tails, no crest on back.

\section{Special Features:}

- Color - Pattern on back may fade to a uniform tan in mature males.

- Behavior - Males vigilantly protect territories, with intense headbobs or push-ups and colorful displays of throat fans.

- Habitat Use - Although frequently found on trees and shrubs, the Brown Anole is a ground-dweller. It never ventures far from the ground, and it rests head down so that it can flee earthward when threatened.

- Activity - Diurnal

Similar Species: $\quad$ Five; two in our range. The Cuban Anole and the Bahaman Anole.

Range and Habitat: Native to Jamaica, Cuba, and the Bahamas and introduced into peninsular Florida. Lives on trees, shrubs, fences, walls, lumber stacks, and rock piles. Usually within $6^{\prime}$ of the ground.

Wild Diet:

Reproduction:

Predators:
Spiders, ants, beetles, grasshoppers, and other insects are caught by swift dashes.

Mates in spring and summer, with single eggs, laid every couple of weeks from June to September. Eggs hatch in 30 days. Courtship involves colorful displays and visual signals.

Birds, larger lizards, and snakes, as well as house pets (dogs and cats). 
This page was intentionally left blank. 


\section{Cuban Treefrog}

Osteopilus septentrionalis

Order: Anura

Family: Hylidae

Description: Largest treefrog in North America. Skin is green, bronze, or gray and warty. Enormous toe pads as large as external ear. Skin on top of head is fused to skull.

\section{Special Features:}

- Activity - Nocturnal

- Feeding - Eats almost anything it can catch and swallow.

- Habitat Use - The Cuban treefrog is most abundant around ornamental fishponds and well-lighted patios. They also hide among the timbers of highway billboards during the day and feed on insects attracted to the lights at night.

- Introduction - This species was probably introduced by accident into Key West on vegetable produce brought from Cuba early in the century. It continues to spread on the Florida mainland by hitchhiking on crates and transplanted shrubs.

- Call - A variable pitched, slightly rasping or grating snore.

Range and Habitat: Introduced into south Florida from Cuba. Can be found in moist and shady places in trees and shrubs or around houses.

Wild Diet:

Reproduction:

Predators:
Insects and native frogs

Eggs deposited in the water in lakes and ponds, drainage ditches, swimming pools, and cisterns from May to October. Males clasp females behind the forelimbs for amplexus or a mating embrace.

Birds, snakes, larger lizards and house pets (cats and dogs).

\section{Notes:}

- A treefrog's pupils are horizontal, and its toe tips expand into sticky adhesive pads used in climbing.

- The Cuban treefrog is extremely invasive and tends to drive native frogs (e.g. the green treefrog) out of their natural habitat. 
This page was intentionally left blank. 


\section{Formosan Subterranean Termite}

Coptotermes formosanus

Order: Isoptera

Family: Rhinotermitidae

Description: Termites live in social colonies that have three castes. The three castes of termites include the Workers, Soldiers and Reproductives. Workers are small, white, blind and quick moving. They perform most of the tasks required to maintain a colony. The majority of individuals in a colony are workers. Soldiers have hard, brown heads with jaws that look like pincers. These jaws are strictly for fighting and are so specialized that they cannot be used to chew food. Some reproductives fly in swarms and start new colonies while others take over reproduction when the primary king or queen dies or becomes separated from the main colony.

\section{Special Features:}

- Foraging Tubes - When these termites invade a house aboveground, foraging tubes of 0.25 to 0.5 inch diameter may be found connecting soil tubes and the infested house.

- Swarming - Swarming is the primary way termites naturally spread after they have been transported to a new area. Three elements are needed for swarming to be effective: 1 ) proper food resources (cellulose or wood), 2) moisture, and 3) a place to colonize.

Similar Species:

The genus Coptotermes contains the largest number of termite pests ( 28 species) among the $>2,500$ termite species worldwide. The Formosan subterranean termite (FST) is the most widely distributed.

Range and Habitat: Native to Asia, the distribution of FST in the United States in the year 2000, included Alabama, California (an isolated infestation in San Diego County), Florida, Georgia, Hawaii, Louisiana, Mississippi, North and South 
Carolina, Tennessee, and Texas. FST nest in the soil to obtain moisture, but they also nest in wood that is often wet. They easily attack any wood in contact with the ground, and if the wood does not contact the soil, they can build mud tunnels or tubes to reach wood several feet above the ground.

\section{Reproduction:}

A single colony may produce over 70,000 reproductive alates. After a brief flight, reproductive alates shed their wings. Females immediately search for nesting sites with males following closely behind. When the pair find a moist crevice with wooden materials, they form the royal chamber and lay approximately 15 to 30 eggs. Within two to four weeks, young termites hatch from the eggs. The reproductives nurse the first group of young termites. One to two months later, the queen lays the second batch of eggs, which will eventually be nursed by termites from the first egg batch.

\section{Notes:}

- How Many?! - A single colony of FST may contain several million termites (versus several hundred thousand termites for native subterranean termite species) that forage up to $300 \mathrm{ft}$ in soil.

- Damage - A single individual of the FST doesn't consume more wood than a single native subterranean termite, however because of its large population size, a FST colony can cause more structural damage in a shorter time.

- Plants - Studies also found that FST attack many species of living plants. The FST attacks structural lumbers and living plants because they are sources of cellulose.

- Pest Status - Control and repair costs due to FST is estimated at $\$ 300$ million annually in New Orleans alone. 


\section{Green Iguana}

Iguana iguana

Order: Squamata

Family: Iguanidae

Description: Full grown usually between 4-6 feet long, although have been known to grow up to 7 feet long. This includes the tail, which can make up about half the body length and has black stripes in addition to its green color. The body is green in color, but can be many different shades ranging from bright green, to a dull, grayish-green or brownish. Their skin is rough, with a set of pointy scales along the iguana's back. They have long fingers and claws to help them climb and grasp.

\section{Special Features:}

- Senses - Green iguanas have excellent senses of smell, hearing and vision.

- Defense - Long, sharp tail is used as a defense mechanism when snapped in the air. The tail can break off if caught by a predator, but grows back without permanent damage, even though this can cause extreme stress to the animal. Skin is very water resistant and tough enough to prevent cuts and scratches. The coloring of the skin helps camouflage the iguana.

- Behavior - Male iguanas have a special flap of skin called the dewlap. Male iguanas can extend their dewlap to appear bigger than they really are in order to intimidate predators or rivals or to impress females.

- Physiology - Both males and females can store fat under their jaws and their necks for times when there is not enough food available.

- Activity - Iguanas are diurnal, awake during the day. Being cold-blooded animals, they bask in the sun, often lying on warm rocks as they soak up the sun's heat. 
Range and Habitat: The green iguana is found over a large geographic area, from Mexico to southern Brazil and Paraguay, as well as on the Caribbean Islands. Iguanas live in tropical rainforest areas, generally in lower altitudes in areas near water sources, such as rivers or streams. They spend most of their time high in the forest canopy, about 40-50 feet above the ground. Have been introduced to South Florida as a result of escaped or released pets, accidental releases in the commercial pet trade, or some other means of invasion.

Wild Diet:

Reproduction:

Predators:
Green iguanas are herbivorous. They eat a variety of leaves and fruits. Sometimes green iguanas (especially young ones) will eat eggs, insects, and small vertebrates.

Iguanas lay many eggs at a time (about 50 ) in holes in the ground called burrows. They also dig burrows without eggs to confuse predators. After the females lay the eggs, they leave them and do not return. Only about 3-10 babies actually survive to adulthood. The egg takes about 8-10 weeks to hatch, then juveniles take about 2 years to become a mature adult.

Snakes, birds, people

\section{Notes:}

- Like many tropical species, the green iguana is also threatened by habitat destruction in its native range.

- The green iguana is a victim of the pet industry. Although many pet iguanas are now being raised on iguana farms, capture from the wild has lowered their numbers.

- Some people in South America hunt the green iguana for food, known as "bamboo chicken".

- These iguanas can dive from trees into water, and swim well. They are quite sturdy and can fall 40-50 feet to the ground without getting hurt.

- Tend to live alone, but occasionally seen in groups in sunny basking spots. 


\section{Green Mussel}

Perna viridis

Order: Mytiloida

Family: Mytilidae

Description: The Green Mussel is a bivalve that can grow to 6 or 7 inches. Shell length is approximately twice the height. Young mussels are a brilliant green and adults are darker green to brown.

\section{Special Features:}

- Size - Florida's native mussels are nearly as large as green mussels, but none of them act as fouling organisms like the green mussel.

- Density - It is not uncommon to find as many as 1,000 adult green mussels per square foot.

- Distinguishing Characteristics - The green mussel can be distinguished from other mussels because it has both a green lip on the inside of the shell and an indented curve on the bottom edge of the shell.

Similar Species: Green lipped mussel and brown edible mussel

Range and Habitat: The green mussel is native to the tropical marine and estuarine waters of the Indo-Pacific region of Asia, from the Persian Gulf to the South China Sea. They live in waters where the salinity ranges from 27-33 PSU, and their optimal temperature range is $26-32^{\circ} \mathrm{C}$ $\left(78.8^{\circ} \mathrm{F}\right.$ to $\left.89.6^{\circ} \mathrm{F}\right)$. The first known occurrence of the green mussel in the United States was in Tampa Bay, Florida, in the summer of 1999, where they were discovered clogging the inside of cooling water intake tunnels at a local power plant.

Wild Diet:

Phytoplankton, zooplankton and detritus filtered from the water 
Reproduction:

Predators:
Sexes in this species are separate and fertilization is external. Spawning generally occurs twice a year between early spring and late autumn. Fertilized eggs hatch and larvae remain in the water column for two weeks before settling as juveniles. Larvae attach to hard surfaces, such as rocks, pilings and boat hulls using strong threads. Sexual maturity occurs after occurs after 2-3 months. Life span typically ranges from $2-3$ years.

Crustaceans, fish, sea stars and molluscs like octopus

\section{Notes:}

- Introduction - Possible methods of introduction include ballast water dumping from ocean-going vessels carrying planktonic larvae, ship hull fouling, aquaculture farms and intentional release.

- Negative Impacts - Competition with the oyster fishery, displacement of native mussels, and carriers of diseases and parasites harmful to native species.

- Control - To date, there has been no successful eradication of marine invertebrates in the United States. To eliminate the source of many introductions, antifouling paints and ballast water management are being researched.

- Food For Thought - Commercial harvesting may be the best way to control green mussel populations. Researchers caution against eating green mussels collected in the wild because little is known about their safety from a human health standpoint, and many Florida waters are closed to shellfish harvesting because of bacterial contamination. Research will determine if green mussels in Florida waters accumulate toxins or harbor parasites. 


\section{House Mouse}

Mus musculus

Order: Rodentia

Family: Muridae

Description: Slightly less than 7 inches long including their tail (tail is about 3 inches long). Color of fur ranges from brown to gray to white. Pointed snout with long whiskers, round ears and thin tails.

\section{Special Features:}

- Life Span - Mice in captivity live as long as 6 years.

- Activity - The house mouse is a nocturnal animal or mainly active at night.

- Mating - Most mice build nests in protected nooks, but some build burrows in the ground.

- Behavior - Teeth continue to grow throughout their lifetime; therefore, they must gnaw on hard things to keep wearing their teeth down.

Range and Habitat: Native to the Indian subcontinent, the house mouse has accompanied humans and colonized, tropical, temperate, semi-desert, desert, and sub-Antarctic regions throughout the world. Lives and breeds in and around buildings.

Wild Diet:

Reproduction:

Predators:
Omnivorous, they eat grain, seeds, grasses, fruit, roots, and stems, and sometimes insects.

Breeds every 10-17 weeks throughout the year. An average of 5-10 young per litter.

Cats, dogs, hawks, owls, weasels, raccoons, snakes, skinks, and people. 


\section{Notes:}

- They are a host to a range of diseases and parasites infectious to humans, the most serious being the bubonic plague.

- A relative of the white mouse; white mice are raised for scientific experimentation.

- House mice are major economic pests, consuming and despoiling crops and foodstuffs, and they have also been implicated in extirpations and/or extinctions of indigenous species in ecosystems they have invaded and colonized that are outside their natural range.

- The house mouse probably has a world distribution more extensive than any other mammal apart from humans. A mouse is extremely adaptable to any domestic environment. 


\section{Hydrilla}

Hydrilla verticallata

Order: Hydrocharitales

Family: Hydrocharitaceae

Description: Sometimes called "water thyme," Hydrilla is a submerged plant found in all types of freshwater. It can grow to the surface and form dense mats. Hydrilla stems are slender and branched. Its small leaves are strap-like, pointed and grow in whorls of four to eight around the stem. Tiny white flowers are visible on long stalks, and potato-like tubers form along the roots that are found in the mud. Hydrilla is a prohibited plant in Florida.

\section{Special Features:}

- Leaves - Hydrilla leaves are small, pointed and arranged in whorls of 4 to 8 . They have serrated margins and one or more sharp teeth under the midrib. Development of the leaves may vary with location, age and water quality.

- Growth Rate - Hydrilla can grow extremely rapidly, up to one inch per day, until it reaches the surface of the water and forms a thick mat that effectively shades any plants below it.

- Length - Plants have been known to reach lengths of up to 50 feet and produce a biomass of more than 130 tons per acre.

Range and Habitat: Historical reports indicate Hydrilla may have originated on the island of Sri Lanka, and DNA analysis points to India's southern mainland. Hydrilla can grow in almost any fresh water including springs, lakes, marshes, rivers and tidal zones of over 20 states.

\section{Reproduction:} Hydrilla reproduces mainly by regrowth of stem fragments, but also by means of axillary buds and subterranean tubers. Tubers can remain viable for more than 4 years and a single tuber can produce as many as 6,000 new tubers $/ \mathrm{m}^{2}$. 


\section{Notes:}

- How did it get here? - The dioecious (having male reproductive parts in one individual and female in another) strain was imported to the U.S. in the 1950s for use in aquariums. It entered Florida's inland water system after plants were discarded into canals in Tampa and Miami. The monecious (having both male and female flowers on the same plant) strain was a separate introduction, first found decades later in the Potomac Basin.

- Distribution of Populations - Southern populations are predominantly dioecious female (plants having only female flowers) that overwinter as perennials. Populations north of South Carolina are essentially monoecious.

- Stats - The most abundant aquatic plant in Florida public waters, $70 \%$ of Florida's freshwater drainage basins contain water bodies infested with Hydrilla.

- Limiting Factors - Very few factors limit Hydrilla because it can grow in shallow and deep water, high and low nutrient concentrations, low or very intense sunlight, and it can withstand cool temperatures.

- Why the Concern - Intakes for drinking water, power generation and irrigation are easily clogged. Shoreline access and boating traffic can be restricted.

- Impacts - Hydrilla grows aggressively and competitively forming thick mats that block sunlight penetration to native plants. It has been shown to alter the chemical and physical components of lakes. Stratification of the water column, decreased oxygen levels, and fish kills have all been documented.

- Money - Florida officials estimate they will spend $\$ 100$ million in a decade to control Hydrilla and water hyacinth. 


\section{Jack Dempsey}

Cichlosoma octofasciatum

Order: Perciformes

Family: Cichlidae

Description: Jack Dempsey are very aggressive cichlid fish found in many colors depending on age and mood, and ranging from a light yellowish-tan with turquoise speckles to a dark brown-blackish color with blue spots. All Dempsey have a thin reddish line along the top edge of their dorsal fin, which is more prominent in males than in females. Young fish are lightly colored with two golden spots along each side and dark stripes along the body. Males are normally larger and more brightly colored than females.

\section{Special Features:}

- Feeding - Jack Dempsey are omnivorous

- Complex Breeding Behaviors - Eggs are laid on the bottom by the female, and then the male or female will fan them with their fins in order to increase the flow of oxygen. When the eggs hatch, one of the adults nearly always remains to defend the young for the first weeks.

- Size - They grow to approximately 8-10 inches.

Similar Species: Similar species include the Rio Grande cichlid, Cichlasoma cyanoguttatum, the Convict cichlid, Cichlasoma nigrofasciatum and the Mayan cichlid, Cichlasoma urophthalmus.

Range and Habitat: Jack Dempsey are native to the Atlantic slope of Central America, from Rio Chachalacas and Rio Paso San Juan, Mexico, to Rio Ulua, Honduras. Jack Dempsey are established in the Gulf of Mexico region only in Florida, where they 
remain uncommon. The recorded populations probably represented several independent introductions. Jack Dempsey are typically found in canals with mud and sand bottoms and drainage ditches rich in aquatic vegetation.

Reproduction:

Jack Dempsey are substrate spawners. Both males and females are extremely aggressive toward other fish when guarding the clutch and the fry that hatch. Approximately 500-800 eggs are spawned per clutch.

\section{Notes:}

- Introduction - They were introduced through intentional or accidental releases from fish farms and recreational aquaria. The recorded populations probably represent several independent introductions.

- Potential Impacts - Given their limited range and population size, Jack Dempsey do not presently constitute a serious threat to the Gulf of Mexico ecosystem. It is uncertain whether the established populations will persist.

- Limitations - As is the case with other cichlids, Jack Dempsey are very resourceful. They are omnivorous and can be found in a great variety of habitats. In addition, they can tolerate relatively cold waters and very low oxygen concentrations. 


\section{Knight Anole}

Anoles equestris

Order: Squamata

Family: Polychrotidae

Description: 13-19" long. Larger lizard with wrinkled bony head, pale pink extensible throat fan, and enlarged toe pads. Snout long and wedge-shaped. Bright green; can change to brown. Yellow or white stripe under eye and over shoulder. Tail slightly compressed. Low crest, most pronounced on neck and shoulders.

\section{Special Features:}

- Behavior - This lizard becomes fiercely defensive when a snake, or anything resembling a snake, such as a stick or a garden hose, gets too close. It turns broadside to the threat, extends the throat fan, raises the back crest, and gapes menacingly. Knight Anoles are relatively slow and can be easily caught by hand, but their strong jaws and sharp teeth should give collectors pause.

- Habitat Use - Arboreal. Under shady canopies of large trees.

- Activity - Diurnal

Range and Habitat: Introduced into Miami-Dade and Broward counties, Florida. Native to Cuba.

Wild Diet: $\quad$ Insects, smaller lizards, and frogs.

Predators: $\quad$ Snakes, large birds, dogs and cats.

\section{Notes:}

- In Florida, this species does not seem to survive cold winters in great number.

- Reproduces in summer. 
This page was intentionally left blank. 


\section{Kudzu}

Pueraria montana variety lobata

Order: Fabales

Family: Fabaceae

Description: Kudzu is a vigorously growing perennial vine in the pea family. Dark green leaves, starchy fibrous roots and elongated purple flowers with a fragrance reminiscent of grapes readily identify this aggressive vine.

\section{Special Features:}

- Growth - Kudzu plants grow rapidly, extending up to or over 60 feet per season at a rate of about one foot per day.

- Leaves - Kudzu leaves are large and compound with three leaflets. Each leaflet has one to three lobes and the two lateral leaflets often are lobed on only one side, whereas the center leaflet has lobes on both sides.

- Roots - Kudzu roots are fleshy, with massive tap roots 7 inches or more in diameter, 6 feet or more in length, and weighing as much as 400 pounds.

- Vines - This vigorous vine may extend 32-100 feet in length, with stems $1 / 2-4$ inches in diameter. As many as thirty vines may grow from a single root crown.

- Flowers - Individual flowers, about a $1 / 2$-inch long, are purple, highly fragrant and borne in long hanging clusters. Flowering occurs in late summer and is soon followed by production of brown, hairy, flattened, seed pods, each of which contains three to 10 hard seeds.

Similar Species: Three-lobed leaves, purple flowers and aggressive growth make Kudzu easy to identify. Similar invasive vines include air potato, which has heart-shaped leaves and fleshy tubers on the tendrils, and skunk vine which has narrow arrow-shaped leaves and smells like skunk.

Range and Habitat: A native of Asia, Kudzu is now common throughout most of the southeastern U.S. and can be found as far north as Pennsylvania. It 
grows well under a wide range of conditions and in most soil types. Preferred habitats are forest edges, abandoned fields, roadsides, and disturbed areas, where sunlight is abundant. Kudzu grows best where winters are mild, summer temperatures are above 80 degrees Fahrenheit, and annual rainfall is 40 inches or more.

Reproduction:

Predators:
The spread of kudzu in the U.S. is primarily due to vegetative expansion by roots and vines. Kudzu also spreads somewhat through seeds, which are contained in pods and mature in the fall. Only one or two viable seeds are produced per cluster of pods and these hard-coated seeds may not germinate for several years.

Kudzu was originally planted all over the South by farmers who hoped to use it as cattle feed. However it grew much faster than the cattle could eat it.

\section{Notes:}

- Background - Kudzu was introduced into the U.S. in 1876 at the Philadelphia Centennial Exposition, where it was promoted for use in erosion control, as a forage crop and as an ornamental plant. Recognized as a pest weed by the U.S. Department of Agriculture in 1953, it was removed from the list of permissible cover plants.

- Management - For successful long-term control of kudzu, the extensive root system must be destroyed.

- Ecological Threat - Kudzu kills or degrades other plants by smothering them under a blanket of leaves, by girdling woody stems and tree trunks, and by breaking branches or uprooting entire trees and shrubs through the sheer force of its weight.

- Miscellaneous Uses - Vines are used to make baskets, leaves are used in cooking and in tea, and a drug extracted from kudzu root may help in the treatment of alcoholism. 


\section{Lionfish}

Pterois sp.

Order: Scorpaeniformes

Family: Scorpaenidae

Size: May reach 14-17 inches.

Description: Lionfish are easily recognized by their elongated venomous dorsal spines and bright stripes. Appendages on the head and around the eyes mask the mouth and eyes. Lionfish appear to hover in the water column. They have been observed hanging motionless at the crest of a reef or ledge waiting for prey to approach.

Range and Habitat: Temperate and tropical Indo-Pacific Ocean. Commonly seen in openings of coral or around pilings in harbors and bays.

Wild Diet:

Crustaceans, worms, smaller fish. Usually prefers live prey.

\section{Notes:}

- There are more than 300 species in the Scorpaenidae family.

- Due to their striking appearance and venomous sting, lionfish are also known as dragonfish, turkeyfish, zebrafish, scorpionfish and firefish.

- $\quad$ Lionfish are primarily nocturnal hunters. These voracious feeders will try to swallow anything they can get into their mouths.

- Lionfish often use their large pectoral fins to trap and corner smaller fish. When feeding on benthic (bottom-dwelling) prey, these fins spread like a net to trap prey.

- The venomous dorsal spines of lionfish are used as a defense mechanism. Lionfish often point these spines toward a predator.

- The sting of a lionfish can be painful, but it is rarely fatal to humans unless multiple stings are inflicted and help is not sought immediately. For immediate treatment, apply very hot water to the afflicted area. 
This page was intentionally left blank. 


\title{
Marine Toad
}

\author{
Bufo marinus
}

Order: Anura (or Salienta)

Family: Bufonidae

Description: Known as the cane or giant toad, marine toads have flat heads. Typically, 4-6 inches long but can reach 9 inches - female is usually larger. Dry skin that is brown with lighter spots and a cream underbelly. Very large eyes and large, triangular parotoid glands. Known to live 40 years in captivity. Nocturnal.

\section{Special Features:}

- Warts - Collections of poison glands. When the toad is attacked, warts exude milky fluid that irritates the attacker's mucus membranes (snakes and birds don't appear to be affected).

- Parotoid Glands - Two sets of poisonous glands behind each eye and extending along the body. When stressed, a marine toad can release enough toxin (milky white fluid) to kill a large dog.

- Tympanic Membranes - In addition to their use in hearing, these membranes, found on just behind the eyes, have been correlated with the ability of the toad to produce sound.

- Call - The Peterson Field Guide (Reptiles and Amphibians, 1991) describes the call of the marine toad as a slow, low-pitched trill, like the exhaust noise of a distant tractor. The mating call is produced by pumping air back and forth over vocal chords.

\section{Similar Species:}

Range and Habitat:

Wild Diet:
Large size and distinctive appearance distinguishes adults from other toads.

Diverse. Native from northern South America to Central America and Texas. Introduced to Haiti, Hawaii, the Philippines, Puerto Rico and Australia for pest control. However, occurrence in southern Florida is the result of accidental releases at Miami International Airport and further sales as pets. Prefers open, damp, leaf-littered fields where insect food is plentiful. Able to flourish in conditions from arid to tropical rainforests.

Having large appetites and being voracious feeders, they will eat just about anything they can catch and fit in their mouths. Use 
persistence, energy and speed to catch prey.

They often feed on worms and insects.

Reproduction:

In early spring, toads move to a breeding pond where males attract females with their calls. Males call while pushing themselves up on their front legs in shallow water. The male clasps the female behind the arms and the pair swims together (referred to as "amplexus") typically until the female comes into contact with some water weed. The female extrudes eggs as a long string while the male ejects sperm over them. This continues for several hours. The female then swims around so the long string of eggs (which is usually 7-10 ft. long) gets wrapped around the water weed. The female can lay up to 35,000 eggs. The tadpoles hatch after 12 days. Time to maturity varies with temperature, usually taking about 3 months.

Predators:

Dogs, snakes, larger frogs and toads, and birds. Dragonfly nymphs and other water insects feed on toad larvae. A small percentage of babies actually reach maturity due to predation.

\section{Notes:}

- Class Amphibia (from the Greek for "both lives") - Along with frogs and salamanders, toads are classified as amphibians.

- Frogs vs. Toads - Frogs usually have moist, smooth skin and are good leapers. Toads have dry, warty skin and usually hop.

- Invasive Species? - Introduced to certain areas, marine toads are beginning to out-compete native species.

- Movie Stars - A documentary about the marine toads' introduction and success in Australia is called Cane Toads: An Unnatural History. Be sure to rent it.

- "Toad Licking" - The secretions of this toad can be made into a hallucinogenic drug. Improper preparation of this drug, including "toad licking," has resulted in deaths.

- NOTE - A person does not get warts from touching toads, but their skin-gland secretions can be irritating to mucus membranes. After handling, remember to keep your fingers away from your eyes and mouth until you wash your hands. 


\section{Midas Cichlid}

Cichlasoma citrinellum

Order: Perciformes

Family: Cichlidae

Description: Midas cichlids can have 6 dusky to black bars on their flanks, a large black blotch on their midside, and a smaller black blotch on their tail fin. Two different color morphs of this species occur. The "typical" morph is gray with a series of markings along its flanks, which vary from bars to large spots. This is the most common morph over the natural range of the Midas cichlid. The second morph may be bright orange to red in color, which is the most common variety found in Florida.

\section{Special Features:}

- Coloration - This species exhibits two basic color morphs, gray and orange. The color varies between the introduced and and native ranges.

- Size - The Midas cichlid often reaches lengths of 9 inches.

Similar Species: There are two species similar to the midas cichlid: the convict cichlid, Cichlasoma nigrofasciatum, and the black acara, Cichlasoma bimaculatum.

Range and Habitat: Over their native range, Midas cichlids are most abundant in lakes with sufficient cover. They thrive in areas rich in macrophytes, sunken bushes and trees, and they frequently inhabit crevices in or between rocks. They have been known to dig burrows under rocks and sunken logs, which they use as cover or for sleeping.

Midas cichlids are native to the Atlantic slope drainages of Central America, from Nicaragua south to Costa Rica. In Florida, they are etablished in Black Creek canal and adjoining canals northeast of Homestead, Miami-Dade County. 
Specimens have also been collected from Broward County and Hillsborough County. This species has not been found in other parts of the Gulf of Mexico ecosystem; however, there is an established population slowly expanding its range on the Atlantic coast of Florida.

Reproduction:

Over its native range this species typically builds nests in caves, crevices among rock piles, or less frequently digs a pit in an open area adjacent to a hard vertical structure. Eggs are deposited on the walls of caves and crevices, or if pits are dug, on the hard vertical structure adjacent to the nest. Males and females care for the eggs.

\section{Notes:}

- Common Names - Frequently called Mojarra; Heros erythraeus and Cichlasoma erythraeum are listed as possible synonyms.

- Means of Introduction - Introductions into Florida were via aquarium or fish farm releases. In other states, introductions most likely represent aquarium releases.

- Importance to Fisheries - Over its native range, the Midas cichlid is among the most popular of food fishes.

- Ecology - The impact of the Midas cichlid is currently unknown.

- Feeding - Midas cichlids frequently feed by sifting through substrates, straining out edible materials, and then spitting the remaining substrate from their mouths. They scrape and pick off food items from rocks and plants. Midas cichlids feed mostly on benthic items, such as snails, other molluscs, algae and insects.

- Life Span - The Midas cichlid may live up to 15 years. 


\section{Nutria}

Myocastor coypus

Order: Rodentia

Family: Myocastoridae

Description: Nutria are large semi-aquatic rodents, smaller than a beaver but larger than a muskrat. Unlike beavers or muskrats, they have round, scaly tails with some hair. The muzzle and chin are white and the ears and eyes are small. The incisors are large and dark orange, protruding beyond the lips. The four inner toes of the hind feet are webbed. Nutrias may be 3 feet long and weigh up to 35 pounds.

Range and Habitat: Nutria are native to South America. Their original range includes Argentina, Chile, Bolivia, Uruguay, Paraguay and southern Brazil, where they are called coypu. After escaping from captivity in the U.S. and elsewhere, they now inhabit a much greater area. Nutria were first imported into the United States between 1899 and 1930 in an attempt to establish a fur farm industry. Many of the fur farms failed in the late 1940 s because fur prices fell and nutria did not reproduce well in captivity. Many nutria were released into the wild. Nutria are now reported throughout the Chesapeake Bay system and in every Gulf state, including Florida. They have caused widespread damage to wetlands in Texas, Louisiana and the Chesapeake. In Florida, possession of nutria requires a license.

Nutria spend their lives in or near water, especially marshes and ponds.

Wild Diet:

Reproduction:
Favorite foods include rushes, reeds, cattails, arrowhead and sawgrass. They will also eat sugarcane.

Nutria breed year-round and are extremely prolific. Males reach sexual maturity at 
4-9 months, and females are sexually mature at 3-9 months. With a gestation period of only 130 days, in one year, an adult nutria can produce two litters and be pregnant with a third! The number of young in a litter ranges from 1-13. Females can breed within a day of having a litter. At birth, young nutria are fully furred and the eyes are open. Newborn nutria feed on vegetation within hours, and they will nurse for 7-8 weeks.

\section{Special Features:}

- Life Span - A nutria's lifespan is about 6 years.

- Behavior - Nutria feed on the roots of plants, severely damaging wetlands by digging underneath and overturning plants to feed on the root mat. Nutria are excellent swimmers, and typically swim with their food to a feeding platform for eating.

- Habitat Use - Although they are generally found in freshwater habitats, some populations inhabit brackish and salt waters.

- Nutritious Nutria? - Although Louisiana officials have attempted to market nutria as a restaurant entrée, it hasn't yet caught on as a popular dinner item. 


\section{Oscar}

Astronotus ocellatus

(Astronotus - marked with star on back; ocellatus - spotted with little eyes)

Order: Perciformes

Family: Cichlidae

Description: Coloration is usually very dark, olive-brown to deep blue-black with pale yellow or orange markings. The base of the caudal fin has a large spot or ocellus bordered with red. Fin coloration varies, usually they are very dark, and occasionally they have ocelli (eyelike colored spots). Eyes are red.

\section{Special Features:}

- Eye Spot - The eyespot on the tail is a common feature among Oscars. The spot is believed to provide a diversion to misdirect the attack of a potential predator toward the tail.

- Growth - Oscars grow very rapidly in a short period of time, and can reach lengths of 14 inches.

Range and Habitat: Over its native range this species is found in the Amazon, Orinoco and La Plata River systems in South America. Due to temperature limitations, their range in Florida is as far north as Tampa Bay. High densities of Oscars are associated with extensive marsh-type and modified habitats (e.g. Everglades basin).

\section{Reproduction:}

Oscars are sexually mature once they reach a length of approximately 5 inches. Fish pair off and often stay together to breed several times. Females lay up to 2000 eggs, which hatch in just a few days. In Florida, spawning occurs from June to October. 


\section{Notes:}

- Introduction - This South American cichlid has been established in Florida waters since the late 1950s when it was first released from a fish farm and spread by anglers who released them in new sites.

- Limitations - Oscars do not tolerate cold temperatures.

- Feeding Habits - Oscars are mainly carnivorous, but they are known to eat plant matter as well. The main components of their diet include fish and insects, with other items such as reptiles taken opportunistically.

- Interest to Fisheries - Oscars are frequently taken by sport fishermen, and they are presently one of the most popular sport fish in southern Florida. In the early 1980s, there was an unexplained increase in numbers, especially in the water conservation areas of the Everglades. With this increase, Oscars grew in popularity as a sport fish. In 1991-1992 the number of Oscars harvested in Everglades water conservation areas was about 53,286.

- Potential Impacts - The impact of this species on native fishes is unclear. There is no concrete evidence of displacement of native fishes by Oscars. However, this species is renowned for its aggressiveness. It may have a significant impact on native fishes through direct predation and competition for breeding areas. 


\section{Peacock Bass}

Cichla ocellaris (This may not be the species in Florida.)

Order: Perciformes

Family: Cichlidae

Description: The peacock bass derives its name from the large conspicuous, black mark (outlined in gold) on its tail. This ocellus resembles the "eye" on the plume of a peacock's tail. Hence the name, "peacock." It generally has a dark greenish-black or bronze back and a light, white belly with the underside being golden, yellow, light chartreuse, pink or blood red. The main body can be green, yellow, gold or dark black, with dusky, black, vertical bars along the sides.

\section{Special Features:}

- Feeding - Peacock bass are exceptionally adaptable because they are voracious predators and will often pursue prey larger than themselves.

- False Eye - The prominent "false eye" on the tail is actually a deceptive target for predators.

- Coloration - The irregular patterns and vivid shades of green, blue, orange and gold obscure the actual eye and detract from its prominence.

- Weight - In their native range, some species grow to a maximum size of $35 \mathrm{lbs}$, whereas other species average 2-4 lbs.

Similar Species:

The taxonomy of peacock bass species is uncertain, and several possible species, including the five prominent ones, have not been thoroughly identified and described.

Range and Habitat: A native of the Amazon and other South American rivers, the peacock bass is an exotic freshwater cichlid in Florida. In its native range, it inhabits marginal lagoons during the dry season and flooded forests during the the rainy season. In the lagoons, it swims in the early morning and at the end of the day. When the 
sun is at its height, peacock bass go to the middle of the lagoons. In rivers without lagoons, it protects itself from currents by remaining behind rocks and sticks. It is not keen on fast-flowing water.

Reproduction:

The peacock bass is a substrate spawner, with approximately 2000-3000 eggs per brood. Breeding pairs guard their clutch for approximately nine weeks, at which time the fry move from open waters to areas rich in vegetation along banks. As is the case with most cichlids, breeding pairs are highly territorial and aggressive.

\section{Notes:}

- Common Names - Tucunare or Pavon

- To Be or Not to Be a Bass? - The peacock bass resembles the black bass, but it is not a member of the same family. It is just one of the 1,600 plus members of the family of fish called cichlids.

- Introduction - Peacock bass are probably the only species of cichlid deliberately introduced into the United States out of the 13 species found here. Released in 1984 by the Florida Game and Freshwater Fish Commission, they were the first exotic species legally introduced into Florida waters. The Florida Game and Fresh Water Fish Commission obtained the breeding stock from several regions of South America. The progeny were released into open waters primarily as a sport fish, but there was also a hope that peacock bass would prey on and control other introduced cichlids. 


\section{Pike Killifish}

Belonesox belizanus

Order: Cyprinofontiformes

Family: Poeciliidae

Description: Pike killifish can easily be identified by their long jaws and large teeth. The origin of the dorsal fin is posterior to the origin of the anal fin. Dorsally, they appear dark olive in color, fading to white at the belly. Several rows of black spots are present on their sides and a black spot is present on the tail fin.

\section{Special Features:}

- Feeding - Pike killifish are ambush predators; they lurk behind plants, roots, and rocks until they strike violently at their prey. Within one day of their birth, young begin feeding on small crustaceans and newborn fish.

- Size - Pike killifish are the largest fish in the family Poeciliidae, and they grow to about 8 inches total length in Florida.

Range and Habitat: Native to Central America, pike killifish were introduced into a canal in Dade County, Florida in November of 1957, after termination of a research project. Over their native range, pike killifish are found along the banks and in the upper water levels of slow moving fresh water streams, in the brackish waters of mangrove and reed swamps, and around inlets of salty bays. In Florida, pike killifish are typically found in shallow waters rich in vegetation or in mangrove swamps. They are seldom present in open waters.

Reproduction:

Pike killifish are live-bearers that breed throughout the year. They are capable of storing sperm for at least 47-56 days, and may produce one brood about every 40 days. Gestation takes between 30 and 50 days. 
Among mature fish, females are larger than males and significantly more numerous.

\section{Notes:}

- Potential Impacts - Pike killifish exert strong pressure on small native fish through direct predation.

- Mosquitoes - Pike killifish like to eat the native eastern mosquitofish, which are predators on mosquito larvae.

- Interest to Fisheries - Pike killifish are of no value as a food fish.

- Predator or Prey? - Due to its torpedo-shaped body and preference for swimming near the surface, the pike killifish is often a preferred prey for larger fish. 


\section{Red-eared Slider}

Trachemys scripta elegans

Order: Testudines

Family: Emydidae

Description: The top of this turtle's shell (carapace) is smooth and gently curved, and it is olive to black with yellow stripes and bars. This medium-sized turtle is best identified by a red or sometimes yellow patch that is found just behind its eye.

\section{Special Features:}

- Habitat Use - Almost exclusively aquatic, red-eared sliders rarely venture far from water except to lay eggs or to migrate to a new water body.

- Activity - Sliders are active at any time of the day; however, feeding usually occurs in the early morning or late afternoon. At night, sliders sleep underwater.

Range and Habitat: The red-eared slider is at home in quiet, freshwater systems that have muddy bottoms and abundant aquatic vegetation. They range from Indiana to New Mexico and down through Texas to the Gulf of Mexico. The slider is commonly seen basking in the sun, on logs or masses of vegetation. Primarily from west of the Mississippi River, they are now common in Florida and other parts of the world, probably due to people releasing their pets.

Wild Diet:

Sliders are omnivorous. Hatchlings and juveniles are more carnivorous, preferring animal matter. As they age, they gradually consume more plant matter. When adult, they show no preference for plants or animals and will eat almost any available food. Prey include insects, crayfish, shrimp, worms, snails, amphibians, and small fish. Algae and 
duckweed are two of the aquatic plants eaten by red-eared sliders.

Reproduction:

Predators:
Mating and courtship usually occur in the spring, but pairs have also been seen in the summer and early fall. Sliders have an elaborate courtship. A male tries to get in front of a female and face her, then he stretches out his front feet and vibrates his claws against the her head and neck. Mating usually takes about 15 minutes, then the female digs a nest outside of the water and lays about 5-20 eggs that take 65-75 days to hatch.

Raccoons, otters, alligators, gars, crows, mink, and muskrats prey on sliders. Occasionally they are caught and eaten by humans.

\section{Notes:}

- These turtles are very popular in the pet trade. 


\section{Tilapia}

- Blackchin tilapia: Sarotherodon melanotheron

- Spotted tilapia: Tilapia mariae

- Blue tilapia: Oreochromis aureus

- Mozambique tilapia: Oreochromis mossambicus

Order: Perciformes

Family: Cichlidae

Description: Females and non-breeding males generally have black dorsal blotches. Breeding males often have a distinct coloration with patches of color on their heads and on the margins of the dorsal and caudal fins. The Mozambique tilapia has 14-20 gill rakers, while Blue tilapia can be distinguished by its higher gill raker count (18-26) in the lower branch of the gill arch. Blackchin tilapia can be distinguished by the black coloration on the underside of the chin and the gold coloration on the operculum. The dorsal fin of spotted tilapia has 16 spines.

\section{Special Features:}

- Adaptations - They quickly grow accustomed to new habitats, and their resistance is absolutely incredible. Because of their ability to adapt to different habitats and, above all, their food value, tilapia have been introduced into many areas both purposefully and accidentally. In Florida, possession of tilapia is regulated.

- Size - Tilapia can reach up to 18 inches in length and weigh well over 1 pound.

Similar Species:

The common name "tilapia" refers to several genera of fishes of the family Cichlidae, order Perciformes, originating in Africa and southwest Asia.

Range and Habitat: Native to Africa and southwest Asia, tilapia are found in lakes, ponds, rivers, streams and canals throughout the tropical and sub-tropical regions of the world. 
Reproduction:

Some species such as the Mozambique tilapia are mouth brooders. Tilapia will excavate a nest on gravel and defend the site against predators. As with many cichlid species, both parents may protect the nest or young. Blue and Mozambique tilapia may become quite aggressive and will chase trespassers 20 or 30 feet from the nest before returning. During breeding season, tilapia build nests in the shallow areas along shorelines. Spawning begins when water temperatures reach $20^{\circ} \mathrm{C}\left(68^{\circ} \mathrm{F}\right)$.

\section{Notes:}

- Aquaculture - Tilapia are one of the major groups of farmraised fish in the world.

- Consumption - Tilapia farming and consumption are rapidly increasing in the US. In fact, in every year since 1995, retail sales of tilapia surpassed those of trout.

- Fisheries Impacts - In Everglades National Park, blue tilapia compete with largemouth bass for nesting sites. Since the largemouth bass fishery represents over $\$ 50$ million annually to the state economy, state officials take this competition seriously.

- Ecological Effects - Tilapia are not generally considered predatory, however in large numbers they are capable of drastically altering habitat and competing for resources. They are capable of reproducing under a wide range of conditions and are known to reach "plague proportions" in some areas.

- Feeding - Tilapia at all sizes feed primarily on phytoplankton and zooplankton, as well as some invertebrates.

- Growth Rate - Tilapia grow fast and may reach sexual maturity at 6 months. Given the resulting fecundity, and their adaptability, it is not surprising that tilapia are abundant. 


\section{Tokay gecko}

Gekko gecko

Order: Squamata

Family: Gekkonidae

Description: About 10-12 inches long. Greenish gray color with gray and orange-brown spots covering the body. The body is slender, topped by a large head. The eyes are prominent in all species and the gecko's vision is excellent. Broad fleshy toes with inner folds.

\section{Special Features:}

- Senses - Just like snakes, they can also use their tongue to smell. They have a special organ on the roof of their mouth called a Jacobson's organ, which takes scent particles from the tongue and relays messages about the surroundings to the brain.

- Call - Common name comes from the sound of their loud call.

- Life Span - Life span is an average of 10 years, but they can live for 20 years in captivity.

- Behavior - Solitary lifestyle, with territories protected by males.

- Activity - Nocturnal

- Reproduction - Oviparous or egg laying

Range and Habitat: From Southeast Asia and Malayan Isles. Live in tropical and subtropical environments. Found among vegetation in rainforests, on mountainsides, on rocky outcrops, and in deserts. Likes to live in bushes, trees and on or around rocks. Now thrives in South Florida, the Caribbean, and Hawaii.

Wild Diet:

Reproduction:
Tokays will eat anything they can catch and chew; crickets, insects, baby mice, baby birds, and small lizards.

Oviparous. Eggs are deposited on the underside of a rock or piece of bark. Females lay 2 or more eggs at a time. Hatchlings are 
about 2-3" long. When hatched they eat their outer covering of skin. They become sexually mature at a year old.

Predators: $\quad$ Snakes, dogs, cats and people

\section{Notes:}

- Tokays do not like to be handled, and they readily bite the hand that feeds them. Therefore, Tokay geckos only make good pets for those who enjoy watching their pets and not handling them. Also, Tokay geckos can be really noisy pets.

- Many Tokay geckos have escaped or been "set free" by their unhappy owners. Now they are an established, invasive species in South Florida.

- Most common around buildings, but also threatens native species in the Everglades.

- Florida now has more non-indigenous species of lizards than indigenous ones.

- The Tokay gecko arrived in Florida through multiple releases. 


\section{Walking Catfish}

Clarias batrachus

Order: Siluriformes

Family: Clariidae

Description: Walking catfish may appear dark brown, gray, or olive with white specks on the latter half of the flanks. Fins are gray-green and there may be red borders on the median fins and some yellow on the dorsal fin. Although all Florida imports were originally albinos (which are tinted yellow at the outer margins of dorsal fins), albinos in the wild are now rare and descendants have reverted to the dominant, dark-color phase, probably a result of natural selection by predators.

\section{Special Features:}

- Locomotion - Snakelike

- Breathing - The gills of the walking catfish are stiffened to prevent collapse while out of water. On land, they keep their gills closed and in the water the gills remain open. On land, they breathe most efficiently using a special part of the gill chamber consisting of spongy organs that grow from the upper ends of the gill arches. These organs are well supplied with blood vessels and operate efficiently on land as well as in low oxygen waters.

- Barbels - Walking catfish possess 4 pairs of barbels: one pair of nasal, one pair of maxillary and two pairs of mandibular barbels.

- Male or Female? - The male of this species is usually more colorful than the female. The most distinguishing feature however, is a dark spot on the rear of the male's dorsal fin.

Range and Habitat: The native range of the walking catfish spans Southeast Asia and includes eastern India, Sri Lanka, Bangladesh, Burma, Indonesia, Singapore and Borneo. They are commonly found in freshwater and brackish water. They can exist in cloudy, low-oxygen waters. 
Wild Diet:

Reproduction:
Omnivore. Walking catfish are mainly active at night and prey on items such as insect larvae, fish eggs, fish and occasionally plant material.

It is reported that walking catfish engage in mass spawning migrations in late spring and early summer. Adhesive eggs are laid in a nest or in submerged vegetation and the males guard the eggs. Juveniles appear in late summer and sexual maturity is attained by the end of the first year.

\section{Notes:}

- Introduction - In the early 1960 s, walking catfish were imported to Florida from Thailand for the aquarium trade.

- Movement - In Florida, dispersal apparently has occurred by way of the interconnected network of canals. However, spread was accelerated by overland migration, typically during rainy nights.

- Impact of Introduction - Largely unknown. In Florida, walking catfish are known to invade aquaculture farms, entering ponds where these predators prey on fish stocks. In response, fish farmers erect fences to protect ponds, though they are inefficient in floods.

- Threats - Cold weather is believed to be the major threat in the introduced range.

- Status - In 1967, the importation or possession of the walking catfish without a permit was outlawed in the state of Florida. 


\section{Water Hyacinth}

Eichhornia crassipes

Order: Liliidae

Family: Pontederiaceae

Description: Known as one of the "world's worst aquatic weeds," the attractive water hyacinth is very deceiving. Large purple flowers once made this plant a popular ornamental species for fish ponds, but it is now illegal in Florida and some other states. Florida officials estimate they will spend $\$ 100$ million in a decade to control water hyacinth and another invasive, Hydrilla.

\section{Special Features:}

- Leaves - This plant only has basal leaves (formed at the base of the stem) that reach up to 6 inches in length. Each leaf is generally rounded, and many of the petioles (the stalks or stems of the leaves) have inflated bases that keep the plant extremely buoyant.

- Flowers - Each flower has 6, bluish-purple petals joined at the base to form a short tube. One petal has a yellow spot. Blooms first appear in late spring, and they continue into late summer, with each plant producing a single spike comprised of 8-15 flowers.

- Fruit - The fruit is a three-celled capsule containing many minute, ribbed seeds.

- Roots - Water hyacinth obtains its nutrients directly from the water, and it is used in wastewater treatment facilities to extract pollutants. Its large root masses make it an efficient water filter.

Range and Habitat: This South American native was introduced into Florida in the 1880 s, and it covered more than 125,000 acres of public lakes and navigable rivers by the early 1960 s. Water hyacinth has become the worst floating, aquatic weed in many tropical and sub-tropical parts of the Americas, Asia, Australia, and Africa. In Africa, it infests every major river and nearly every major freshwater lake. In the United States, it 
flourishes in hundreds of bodies of water in Hawaii, California and throughout the south from Texas to the Carolinas.

Reproduction:

Water hyacinth reproduces sexually by seeds and vegetatively by budding. The seeds can germinate in a few days or remain dormant for 15-20 years. They usually sink and remain dormant during periods of stress (drought). Upon reflooding, the seeds germinate and renew the growth cycle.

\section{Notes:}

- Growth Rates - The growth rate of water hyacinth is among the highest of any plant. In Florida, water hyacinth populations can double in as little as 6-18 days by sending off short runner stems, which develop new plants.

- Effects - Water hyacinth blocks waterways and limits boat traffic, recreation, flood control and wildlife use. By shading and crowding out native aquatic plants, this exotic species reduces biological diversity in aquatic ecosystems.

- Fish - Large water hyacinth populations can adversely affect fish populations. As vegetation continually falls to the bottom, it decays and consumes oxygen. Certain species of fish cannot tolerate low levels of oxygen. One acre of water hyacinth can deposit approximately 200 tons of decaying plant material on the bottom of a water body each year. The nutrients in these decaying plants are released back into the water to support growth of more water hyacinth.

- Methods of Control - 1) herbicides, 2) direct harvesting and 3 ) biological control, including the use of two weevil species (Neochetina spp.) and a moth (Sameodes albiguttalis). 